\title{
Did Trade Liberalization Help Women? The Case of Mexico in the 1990s
}

\author{
Ernesto Aguayo-Tellez \\ Universidad Autónoma de Nuevo León \\ Jim Airola \\ Monterey Institute of International Studies \\ Chinhui Juhn ${ }^{1}$ \\ University of Houston \\ Carolina Villegas-Sanchez \\ ESADE-Universitat Ramon Llul
}

June 2012

\begin{abstract}
With the signing of the North American Free Trade Agreement (NAFTA) in 1994, Mexico entered a bilateral free trade agreement which not only lowered its own tariffs on imports but also lowered tariffs on its exports to the U.S. We find that women's relative wage increased, particularly during the period of liberalization. Both between and within-industry shifts also favored female workers. With regards to between-industry shifts, tariff reductions expanded sectors which were initially female intensive. With regards to within-industry shifts, we find a positive association between reductions in export tariffs (U.S. tariffs on Mexican goods) and hiring of women in skilled blue-collar occupations. Finally, we find suggestive evidence that household bargaining power shifted in favor of women. Expenditures shifted from goods associated with male preference, such as men's clothing and tobacco and alcohol, to those associated with female preference such as women's clothing and education.
\end{abstract}

Corresponding author: Chinhui Juhn: Department of Economics, University of Houston, Houston, TX 772045882, (Tel) 713-743-3823, (Email) cjuhn@,uh.edu 


\section{Introduction}

Gender equality, along with ending hunger and poverty, is one of the eight stated goals in the U.N. Millennium Development Goals Report (UN, 2009). Given that many developing countries have adopted trade reforms, an important question is whether trade liberalization policies will further or hinder the goal of gender equality. Furthermore, equity concerns aside, the effect of liberalization policies on gender outcomes may be of interest from the point of view of economic growth since there is now growing evidence that empowering women promotes education and better children's outcomes (Thomas (1990), Duflo (2000), Qian (2008)). Quoting from a recent paper by Duflo (2011), “empowerment [of women] can, in other words, accelerate development."

In this paper we examine the impact of tariff reductions associated with the signing of the North American Free Trade Agreement (NAFTA) on gender outcomes in Mexico. Relative to the existing literature, our paper makes the following contributions. While most papers focus on the gender wage gap, our paper also examines employment as well as wage changes. ${ }^{2}$ Using the labor demand approach taken to study U.S. wage inequality (Katz and Murphy (1992), Berman, Bound, and Griliches (1994)), we decompose the overall increase in female employment and wage bill shares into "between" and "within" industry components, and link these changes to

\footnotetext{
${ }^{2}$ Papers which examine the gender wage gap include Brown, Pagan, and Rodriguez-Oreggia (1999) which decomposes the gap into the component due to differences in characteristics between men and women and the component due to discrimination. Pagan and Ullibarri (2000) find that the gender gap is larger for older workers, larger in smaller firms, large in the informal sector, and larger at the border. Sanchez and Pagan (2001) find a large earnings gap between female and male-owned micro-enterprises which is partly explained by lower levels of education and experience of female owners although surprisingly, not much is explained by differences in sectoral composition of female and male-owned businesses. Oostendorp (2004) presents cross-country analysis relating the gender gap to measures of trade and FDI. The paper finds that trade and FDI inflows reduce the gender gap among low skilled occupations while results are mixed for high skilled occupations. A recent volume, Bussolo and De Hoyos (2009) also examine the link between trade liberalization and poverty through the channel of women's labor market outcomes.
} 
tariff changes across sectors. Finally, ours is the first paper we are aware of that examines household expenditure patterns to assess changes in women's well-being as well as income.

What are some possible theoretical links between trade liberalization policies and gender outcomes? If men and women are imperfect substitutes in production, the labor demand framework that has been used for skill demand can be applied to discuss and quantify relative demand for female workers. ${ }^{3}$ In this framework, industries utilize male and female workers in different intensities, and trade liberalization, by affecting the relative size of industries, will generate demand shifts by gender. For this to be an important channel, we should observe substantial labor re-allocation towards those sectors which are female-intensive. ${ }^{4}$

Another channel through which trade liberalization policies can affect gender outcomes is through technology. In an effort to explain rising wag inequality within industries as result of trade liberalization, recent theoretical papers in trade have built models with product differentiation, increasing returns, and heterogeneity across firms (Melitz (2003), Yeaple (2005)). In these models, tariff reductions encourage the more productive firms to enter the export sector. Verhoogen (2008) and Bustos (2011) show that these exporting firms also upgrade quality and technology, thereby increasing the demand for skilled workers. While most of the focus in the literature has been on the impact of technology on skill demand, technology upgrading may also complement female workers by being complementary with cognitive skills and reducing the demand for physical skills. ${ }^{5}$ Juhn, Ujhelyi and Villegas-Sanchez (2012)

\footnotetext{
${ }^{3}$ See for example, Katz and Murphy (1992), Bound and Johnson (1992), Berman, Bound, and Griliches (1994). This framework is adopted by Acemoglu, Autor, and Lyle (2004) who examine the impact of WWII mobilization rates on female labor supply and consequently on their relative wage. Their estimates of the elasticity of substitution between men and women suggest that "men and women are close but far from perfect substitutes."

${ }^{4}$ Alternatively, one may assume that men and women are perfect substitutes in production but women have lower levels of skill. This is the assumption, for example, in Bussolo and De Hoyos (2009)). There is little evidence, however, that trade liberalization raised relative wages and employment of less skilled workers.

${ }^{5}$ Galor and Weil (1996) and Welch (2000) explore the notion that women have advantage in cognitive vs. physical skills and that advances in technology increase the relative demand for women over time. Using U.S. data,
} 
consider a model where men and women differ in terms of their capacity to perform physically demanding tasks. In their model, the introduction of new technology lowers the need for physical skills thereby benefitting women. They find that firms which upgraded technology also shifted towards hiring more female workers in blue-collar jobs, but not white-collar jobs. To the extent that exports and technology upgrading is an important channel, we should observe shifts towards female labor within sectors, and this type of activity should be concentrated in sectors with larger export tariff reductions.

A third channel is through the reduction of discrimination brought about by foreign competition. Building on the insight of Becker (1957), Black and Brainerd (2002) report that U.S. industries which were subject to more competition through trade experienced greater reductions in the gender wage gap. ${ }^{6}$ A recent paper by Ederington, Minier, and Troske (2010) find that trade liberalization in Colombia increased employment of women relative to men in blue-collar occupations - a change the authors attribute to increased product market competition and reductions in employer discrimination. This channel suggests that we should observe a systematic relationship between reductions in import tariffs and female wages and hiring. We examine each of these channels in our empirical work.

To summarize our findings, we find that trade liberalization policies improved women's labor market outcomes in Mexico. First, relative wages of women increased even as employment rates increased, and this pattern is particularly pronounced during the trade liberalization period, 1990 to 2000. In contrast to studies conducted in the U.S. (Berman, Bound and Griliches (1994)) and Mexico in an earlier period (Revenga (1997), Hanson and Harrison (1999)), we find

Weinberg (2000) shows that female employment growth is positively related to computer-use across industries and occupations. Also using U.S. data and Dictionary of Occupation Titles (DOT) Rendall (2010) shows that occupations which are more "brain" intensive have expanded over time, favoring female workers.

${ }^{6}$ Artecona and Cunningham (2002) employ the same methods for Mexico but do not find a significant relationship between tariff changes and reductions in the gender wage gap across industries. 
evidence of substantial labor reallocation across industries, shifting employment towards initially female-intensive sectors. Between-industry shifts, usually thought to be consistent with tradebased explanations, account for up to 40 percent of the increase in wage bill share of women from 1990 to 2000. Comparing across industries, we find that tariff reductions were positively related to industry growth and concentrated in initially female-intensive industries. We also find evidence that within-industry shifts favored women. Using establishment-level data for the manufacturing sector we find that larger declines in export tariffs (U.S. tariffs on Mexican goods) are associated with larger increases in wage bill shares of women in skilled blue-collar occupations. This result suggests that the exports and technology channel emphasized in the recent trade literature may be important for explaining gender outcomes as well as skill premiums. We find a much weaker relationship between reductions in import tariffs and female wage bill shares, however, suggesting that reductions in discrimination brought about by trade liberalization played a relatively minor role in the Mexican case.

Women's relative earnings increased but are they necessarily better off? We end with suggestive evidence that women's bargaining power within the household improved along with their relative earnings. Household expenditures shifted from goods associated with male preference, such as men's clothing and tobacco and alcohol, to those associated with female preference such as education and women's clothing.

This paper is organized as follows. Section II briefly describes the trade liberalization policies behind the signing of NAFTA. Section III examines aggregate changes in relative wages and employment of women. Section IV examines between and within industry shifts and their associations with tariff changes. Section V reports the results on household expenditure patterns. Section VI concludes. 


\section{Mexico’s Trade Liberalization under NAFTA}

Mexico implemented unilateral tariff reductions in the 1980s to join the GATT in 1986. By 1987 , the highest tariff was reduced to $20 \%$ and the tariff structure was simplified to include only 5 different rates: $0 \%, 5 \%, 10 \%, 15 \%, 20 \%$. Starting in 1990, Mexico's opening strategy switched to pursuing bilateral free trade agreements, with the most important being the North American Free Trade Agreement (NAFTA) with U.S. and Canada which took effect in 1994. NAFTA reduced tariff rates with the U.S. from a maximum of $20 \%$ to zero in 15 years and many of the reductions to zero took immediate effect (Zabludovsky, 2005). Figure 1 shows trends in effective tariff rates separately for U.S. and other non-NAFTA countries. Table 1 reports tariff changes by industry. Columns (1) and (2) show Mexican import tariffs in 1993 before NAFTA as well as the change in tariffs from 1993-2000. Columns (3) and (4) report U.S. tariff levels in 1993 and the change from $1993-2000 .^{7}$ The table illustrates the bilateral nature of the agreement where reductions in Mexican tariffs were accompanied by corresponding reduction in U.S. tariffs. "Textiles" and "Clothing" are especially notable in that NAFTA abolished relatively high tariffs in these industries on both sides of the border. ${ }^{8}$ Since more than $80 \%$ of the trade occurs with the U.S., the decline in effective tariffs resulted in dramatic increases in trade flows. Figure 2 shows the trends in exports and imports as fractions of GDP. The figure shows that while the unilateral tariff reductions had some impact in the 1980s, trade flows accelerated in the 1990s.

\footnotetext{
${ }^{7}$ The Mexican tariff data are from the volume published by Ministry of the Economy (formerly SeCOFI), Fracciones Arancelarias y Plazos de Desgravacion, Tratado de Libre Comericio de America del Norte (1994). The U.S. tariff data are from John Romalis, as described in Feenstra, Romalis, and Schott (2002). For both Mexican and U.S tariffs, we begin with 8-digit harmonized tariff system categories and aggregate up to 3-digit SCIAN97 (NAICS) categories using initial import and export shares. Details of the construction of the tariff data are in the data appendix.

${ }^{8}$ The correlation of Mexican and U.S. tariffs changes reported in the table is approximately 0.3 .
} 
Interestingly, trade flows appear to have stagnated again in the 2000s mostly likely due to a recession in the U.S. and China's entry into the WTO.

\section{Changes in Women's Relative Wage and Employment before and after NAFTA}

\section{A. Women's Relative Wage}

Figure 3 documents changes in relative wage of women during the period 1984-2004.

We use multiple rounds of a representative household survey, Household Income and Expenditure Surveys (ENIGH) and the 10\% samples of the Mexican Population Census of 1990 and 2000 available from the Census IPUMS. Our wage sample consists of men and women who are 15-64 years old, who reported working full-time (30 hours or more), and who either did not have self-employment earnings or reported that they were not self-employed. Additionally, since we are calculating means in figure 3 , we are wary of outlier observations and proceed by deleting the top and bottom 1 percent of observations by gender. ${ }^{9}$ Details of the data construction and sample selection statements are in the data appendix.

Figure 3a graphs the mean female-male wage ratio. Using multiple rounds of the ENIGH household survey, we estimate annual rates of change in the female-male wage ratio for three separate periods, 1984-1989, 1989-2000, 2000-2004, by regressing the female-male wage ratio on a linear spline with break points in 1989 and 2000. In figure 3a, we graph the predicted value as well as the actual female-male mean wage. We estimate an annual rate of decline of 1.1 percentage points in 1984-89, an increase of .4 percentage points annually during 1989-2000, and a decline of .5 percentage points annually during 2000-2004. All but the last estimate is

\footnotetext{
${ }^{9}$ We experimented with various alternative cutoffs and other measures such as medians and log wage differences and found similar trends in relative wages.
} 
statistically significant. ${ }^{10}$ The Census data indicate that female-male wage ratio increased approximately 2.7 percentage points from 1990 to 2000 . Note that figure 2 showed accelerated increase in trade flows during 1990-2000 in comparison to either before or after. Similarly, in figure 3a, we estimate a rising trend in the female-male wage ratio during the 1990-2000 period, and declining trends in periods before and after.

One concern is that women's education levels may have increased relative to men and this may be driving the above changes in relative wages. Figure $3 \mathrm{~b}$ addresses this issue by calculating mean wage ratios holding the composition of workers fixed across age and education categories. ${ }^{11}$ Figure $3 \mathrm{~b}$ illustrates that correcting for compositional changes makes little difference. In figure $3 \mathrm{c}$ we examine whether deleting self-employed workers substantially biases our results. We include self-employed workers in figure $3 \mathrm{c}$ and find similar trends. Finally, in figure $3 \mathrm{~d}$ we examine the most inclusive sample by including self-employed workers and parttime workers. We report hourly wages by dividing weekly wage by hours worked per week. We find that women are paid slightly better than men on an hourly basis (the ratio is often greater than 1) and moreover, both in the ENIGH and the Census, hourly wages of women increased relative to wages of men during the 1990s. This suggests that we may be slightly understating wage gains of women by focusing on full-time wage and salary workers. The basic message we take away from figure 3 is that women's relative wage increased slightly and certainly did not decrease during the period of trade liberalization, 1990 to 2000.

\section{B. Employment and Female Share of the Labor Force}

\footnotetext{
${ }^{10}$ We define our regressors as $\mathrm{s} 1=\min ($ year-1984,5), $\mathrm{s} 2=\max (0, \min ($ year-1989,11)), and $\mathrm{s} 3=\max (0, \mathrm{year}-2000)$ and graph the predicted values from the regression.

${ }^{11}$ In order to hold composition across education and age constant, we first calculated average wages by single-year age and education categories and aggregated over these groups using a fixed distribution across all years.
} 
We next examine changes in employment to population ratios of women and men as well as changes in the female share of the labor force. Table 2 reports the employment to population ratios of women (top panel) and men (bottom panel) who are 15-64 years old. Employment rates (especially of women) are much lower in Mexico than the rates observed in developed countries. For example, the ratio for comparable women in the U.S. during this period would be .60 and higher, while in Mexico the rate is still only .44 in 2004. Employment rates did rise rapidly for women, however, over the entire period, while employment of men increased much more modestly. Over the 1990s, the employment-population ratio of women increased 12.3 percentage points (ENIGH) and 13.4 percentage points (Census) in the two surveys.

Table 3 describes the changes in female share of the labor force. Top panel reports shares based on the ENIGH while the bottom panel refers to data from the Census. Panel A reports female share of total hours worked. Panel B reports labor shares in efficiency units. ${ }^{12}$ Focusing on the Census-based results in the bottom panel, the table shows that both measures of female labor share increased by approximately 5 percentage points with the change in hours shares being slightly larger.

The decline in the female/male wage ratio from 1984 to 1989 is consistent with the increase in the relative supply of women where rapid entry of women led to a decline in own wage. Over the period, 1989-2000, relative wage of women increased even as their labor share increased. Taken together, the evidence on the gender wage gap and relative supplies suggest that relative demand for women must have increased. In the special case of Cobb-Douglas production where the elasticity of substitution between male and female labor equals one, we can interpret changes in female wage bill share as an increase in relative demand for female labor

\footnotetext{
${ }^{12}$ To calculate shares in efficiency units, we weight hours by the group specific average wage which is fixed over years. In addition to men and women, we define 10 five-year age groups and 5 education groups.
} 
(see Autor and Katz (1999)). Wage bill shares are reported in Panel C and the table shows that wage bill shares of women also increased by approximately 5 percentage points. ${ }^{13}$ The evidence on the last period, 2000-2004, is mixed. On the one hand, relative wage declined. Table 3 shows, however, that women's labor share increased most rapidly over this period and taken together, wage bill share also increased. Interestingly, the increase in wage bill share since the year 2000 was entirely due to educated women, those with at least 12 years of schooling. Wage bill shares of women with less than 12 years of schooling actually declined 2000-2004.

\section{Women's Labor Market Outcomes and Trade Liberalization}

\section{A. Between-Industry Shifts in Female Wage Bill Share}

Table 4 reports labor shares across broad industry classes using Census data. The most significant change reported in the table is the declining share of agricultural employment throughout the period. Agriculture's share fell from 12.5 percent in 1990 to 7.7 percent in 2000 . As indicated in column (3) female labor share in agriculture in 1990 was only 2.9 percent. Since predominantly men work in agriculture in Mexico, we would expect this to negatively impact men relative to women. Somewhat surprisingly, the manufacturing sector also decreased modestly. Instead, several services sectors registered large growth, such as professional services, education, hotel and restaurants, and other services.

\footnotetext{
${ }^{13}$ In calculating wage bill shares, we also allow group specific wages to vary by year. More specifically, we define 10 five-year age groups and 5 education groups. We use our wage sample to calculate average wage of group $\mathrm{j}$ in year $\mathrm{t}$ in the following manner: $W_{j t}=\frac{\sum_{i \in j} \text { Wageinc }_{i t}}{\sum_{i \in j} \text { Hours }_{i t}}$ and use our quantity sample to sum total hours by group $\mathrm{j}$ in year

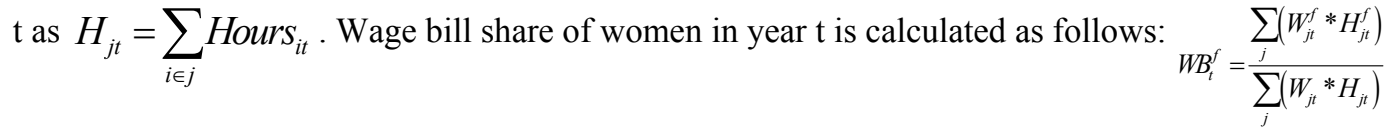


Table 5 disaggregates the manufacturing sector further and shows that while manufacturing employment was flat overall, there have been winners and losers within manufacturing. Female-intensive sectors (based on initial female share in 1990) such as "clothing" and "computers and electronics" grew while predominantly male-intensive sectors such as "petroleum and coal products," "chemicals" and "primary metal" declined. "Transportation equipment" which includes car assembly, on the other hand, grew over this period.

One method of summarizing these changes is to calculate within and between-industry changes in employment and wage bill shares of female workers. Between-industry changes in women's wage bill share would be consistent with trade based explanations. For example, tariff reductions associated with NAFTA may have increased the relative size of textiles and clothing sectors which more intensively utilizes female labor. These types of changes would be captured by between-industry shifts and we view gauging the importance of between-industry shifts as the first step towards assessing the role of trade liberalization policies.

We decompose the change in the female share into two components according to the following formula:

$\Delta$ Female_share $_{t}=\sum_{i} \frac{E_{i t-1}^{f}}{E_{i t-1}} *\left(\Delta \frac{E_{i t}}{E_{t}}\right)+\sum_{i}\left(\Delta \frac{E_{i t}^{f}}{E_{i t}}\right) * \frac{E_{i t}}{E_{t}}$

The term $\frac{E_{i t-1}^{f}}{E_{i t-1}}$ is the share of women in industry $i$ and $\Delta \frac{E_{i t}}{E_{t}}$ is total employment growth of industry $i$. The first term corresponds to the "between" component and captures the extent to which growth in female share was due to differential growth across industries. The second term reflects within-industry changes in female share. We use 69 industry classifications which we can consistently match across the 1990 and 2000 Census. 
The top panel of table 6 reports changes in employment shares (in efficiency units) as well as changes in wage bill shares for all sectors. We distinguish 4 different groups, less educated $(<12$ years of schooling) males and females, and more educated $(>=12$ years of schooling) males and females. We also report all women's wage bill share in the last row. The table shows that the wage bill share of women increased 5.3 percentage points overall between 1990 and 2000. Between-industry shifts account for 40 percent (2.1/5.25) of the total change. Between-industry shifts account for a smaller (32 percent) but still substantial share of the change in employment share suggesting that employment shifts across industries were important.

The middle and bottom panels of table 3 show similar results for the 29 industries in the tradeables sector (including agriculture) and for 21 industries in the manufacturing sector. Taken together, approximately between one-third and up to 40 percent of the rise in female wage bill share can be attributed to between-industry shifts. These results stand in sharp contrast to Attanasio, Goldberg, and Pavcnik (2004) who find stable employment patterns across industries in Colombia and also Revenga (1997) and Hanson and Harrison (1999) who examine an earlier period in Mexico. These authors conclude that trade liberalization impacted industry wage premiums rather than reallocated labor across sectors. Our finding here is that labor reallocation is an important part of the story in Mexico during the 1990s. It is also important to keep in mind that the lack of detail in our industry categories is likely to under-estimate the true shift in employment across industries thus giving us a lower bound of the importance of betweenindustry shifts.

Can these between-industry shifts be linked to trade liberalization policies? Note that the "between industry" shift consists of the following expression from equation (1):

Between $=\sum_{i} \frac{E_{i t-1}^{f}}{E_{i t-1}} *\left(\Delta \frac{E_{i t}}{E_{t}}\right)$. The first term, $\frac{E_{i t-1}^{f}}{E_{i t-1}}$, refers to female share in the industry in 
the initial period, while the second term, $\left(\Delta \frac{E_{i t}}{E_{t}}\right)$, refers to industry growth. We show below

that trade liberalization (tariff reductions) is positively related to increase in industry share

$\left(\Delta \frac{E_{i t}}{E_{t}}\right)$ and also initial female share $\frac{E_{i t-1}^{f}}{E_{i t-1}}$

Figure 4 relates the change in total industry wage bill share, $\left(\Delta \frac{E_{i t}}{E_{t}}\right)$ from 1990 to 2000

to the change in industry level tariff rates from 1993-2000 for the 29 industries in the tradeables

sector. ${ }^{14}$ As illustrated in figure 4, larger tariff reductions are positively related to industry

growth. ${ }^{15}$ It is interesting to note that this is contrary to the predictions of the standard

Heckscher-Ohlin (HO) trade model, which would predict contraction among sectors that

experienced a decline in their output price (due to tariff reductions). We find that tariff

reductions from 1993-2000 are positively related to industry growth. Although it is not clear

why Mexico would have protected industries in which it has a comparative advantage, the

coincident reduction in tariffs by the U.S. likely had a large effect especially in the most

impacted industries such as textiles and clothing. In addition, recent papers have pointed out

that trade liberalization not only reduces output prices but also the prices of imported

intermediate products. Tariff reductions could lead to the expansion of domestic firms by

reducing cost of existing imports as well as by allowing firms to increase scope and expand to

\footnotetext{
${ }^{14}$ These are the industries for which we are able to match both across Census years and also to the tariff data using the Sistema de Clasificacion Industrial de America del Norte 1997 (SCIAN97). We do not utilize establishment level data from the ENESTyC in this section for two reasons. First, the ENESTyC includes only manufacturing firms and we would lose the agricultural sector. Second, the ENESTyC oversampled small firms in 2000 but we do not have clear details of the oversampling. Since our objective in this section is to get a representative overview of the tradeables sector, we rely on household data instead.

${ }^{15}$ Figure 4 also shows that the agricultural sector is an outlier which may be due to the fact that tariff changes in agriculture were slowly implemented with the last of the reductions scheduled to go into effect in 2008. In preparation, however, the government implemented land reforms and began to dismantle price supports and subsidies which resulted in a steep decline in agricultural employment well before the tariff reductions. Running the regression without agriculture results in a coefficient equal to -.001 with t-stat of -1.86 .
} 
new product varieties (Amiti and Konings (2007) and Goldberg, Khandelwal, Pavcnik, and Topalova (2010)).

The next question is whether tariff changes were concentrated in initially femaleintensive industries. In figure 5, we graph initial female share in the industry in 1990 against tariff changes. The figure shows that the largest declines in tariffs were concentrated in initially female-intensive industries, with "clothing" playing an important role in terms of both female share and tariff declines. ${ }^{16}$

\section{B. Within-Industry Shifts in Female Wage Bill Share}

While table 6 showed that up to 40 percent of the increase in female wage bill share was due to between-industry shifts, the table also showed that majority of the increase occurred within industries. In this section we examine what may account for the rise in female wage bill share within industries. To examine this question, we use establishment level data, Encuesta Nacional de Empleo, Salarios, Tecnologia y Capacion (ENESTyC). ENESTyC is a survey of establishments in the manufacturing sector and was carried out in 1992, 1998, and 2001. We use the 1992 and 2001 samples in our analysis which refer to the years 1991 and $2000 .{ }^{17}$ Table 7 provides a summary of the main variables. Particularly notable is the increase in the number of exporting firms from 43 percent in 1991 to 55 percent 2000.

To investigate the link between within-industry shifts in female wage bill share and trade liberalization policies, we consider the following regression at the establishment level:

\footnotetext{
${ }^{16}$ The relationship is still negative although somewhat weaker without the "clothing" industry. If we exclude "clothing," the regression coefficient is reduced to -.007 with t-stat of -1.79 .

${ }^{17}$ We drop micro establishments (those with 15 employees or less) from the analysis since micro establishments were oversampled in 2001 but we do not have clear details of the oversampling. We would like to thank INEGI officials for granting on-site access to the establishment level data used in this study under the commitment of complying with the confidentiality requirements set by the Mexican Laws and in particular, to Maria Luisa Meza Leon, Lizi Ivette Gonzalez Jimenez and Gabriel Romero Velasco.
} 
Female_Share $_{j i t}=\alpha+\beta_{T 1}$ Tariff $_{i t}+\beta_{X} X_{j i t}++\eta_{t}+\lambda_{i}+\varepsilon_{j i t}$

where Female_Share jit $_{\text {rit }}$ represents the female wage bill share in establishment $j$ in industry $i$ in year $t$, Tariff $f_{i t}$ refers to industry tariff levels in 1991 and 2000, $X_{j i t}$ refer to various establishmentlevel controls, and $\eta_{t}$ and $\lambda_{i}$ refer to year and industry fixed effects. While all tariffs are expected to be eventually reduced to zero under NAFTA, not all industry tariffs had been reduced to zero by 2000 , and one concern is that the actual timing of the changes may be endogenous and subject to more political pressures and contemporaneous industry performance. We therefore use initial tariff levels in 1991 interacted with 2000 year dummy as our main regressor. We estimate the following equation:

Female_Share $_{j i t}=\alpha+\beta_{T 1}$ Init_Tariff $_{i} * 200$ _Dummy $+\beta_{X} X_{j i t}+\eta_{t}+\lambda_{i}+\varepsilon_{j i t}$

In the above specification the coefficient $\beta_{T 1}$ compares female wage bill shares in 2000 across industries with different initial tariff levels, controlling for industry fixed effects, $\lambda_{\mathrm{i}}$. Since industries with higher initial tariff levels experienced larger declines, we expect the sign of $\beta_{T l}$ to be positive. Unlike the previous sections where we were limited to 3-digit industry classifications, we have more detailed industry information, 6-digit level of the Mexican Classification of Activities and Products system (CMAP), available in the establishment level 
data. Tariff data, both Mexican tariffs on imports (import tariffs), as well U.S. tariffs on Mexican exports (export tariffs), were merged at the CMAP level. ${ }^{18}$

Table 8 reports the results from estimating equation (3). The top panel refers to export tariffs while the bottom panel refers to import tariffs. Column (1) reports the results for overall female wage bill share, while columns (2)-(5) examine various subcategories such as whitecollar (column 2), blue-collar (column 3), “specialized blue-collar” (column 4), and "general blue-collar" (column 5). While the coefficients are generally positive, indicating that larger declines in export tariffs lead to greater increase in female wage bill share, most of the coefficients are not significant at the 5 percent level. The one exception is female wage bill share in "specialized blue-collar" category, the skilled blue-collar occupations. ${ }^{19}$

What is the channel which links reductions in export tariffs to increases in female wage bill share? Recent papers have emphasized productivity differences between exporting and nonexporting firms (Bernard and Jensen (1999), Verhoogen (2008), and Bustos (2011)). In particular, Bustos (2011) shows that in the aftermath of the regional free trade agreement between Argentina and Brazil, the MERCOSUR, the number of exporting firms increased. In a paper that builds on a model of firm heterogeneity and worker heterogeneity along gender and skill dimensions, Juhn, Ujhelyi and Villegas-Sanchez (2012) find that reductions in export tariffs increased the number of exporting firms and these firms adopted technology which appears to be

\footnotetext{
${ }^{18}$ We thank Leonardo Iacovone for providing us with the tariff data. Tariff data were available originally at the 8digit Harmonized System (HS) classification and was matched to the Mexican CMAP class classification as explained in Iacovone and Javorcik (2010).

${ }^{19}$ Since maquiladoras were not subject to import duties or tariffs even before the trade liberalization, it is not clear how tariff reductions would impact this type of activity. For this reason, we exclude maquiladoras and firms who earned more than $50 \%$ of their income from maquiladora activity from our analysis. Additionally we include in our sample those firms who are in size categories 1 and 2 (greater or equal to 100 employees) and hire at least one female employee. The size restriction is due to the fact that the ENESTyC oversampled small firms in 2000 but we were unable to obtain clear details regarding sampling weights. Restricting the sample to larger firms ensures comparability across the two years. Our results are qualitatively similar although slightly weaker without these restrictions. Additional controls in the regression include age of firm, age squared, $\log$ (Capital/Value Added), $\log ($ Value Added), R\&D expenditures as share of total income, share of white-collar workers, and foreign dummy which is equal to one if at least 10 percent of assets is foreign-owned.
} 
more complementary with female blue-collar workers. While we show only the reduced relationship between tariffs and female wage bill share in table 8 , our results are broadly consistent with this technology based explanation.

Finally, another channel is the role of competition and discrimination. The bottom panel of table 8 addresses this issue by using the same specification as (3) but using Mexican tariffs (import tariffs) as the independent variable. While the coefficients are positive, table 8 shows that the relationship between import tariffs and female share is much weaker. These results suggest that increased competition and reductions in discriminatory hiring practices were most likely of secondary importance in Mexico.

\section{Household Expenditures and Shifts in Household Bargaining}

We have shown that during the period of trade liberalization women's wage remained stable while they worked more (at least in the non-household sector). This brings us to the question of whether women's well-being improved as a result. Recent papers on household bargaining have rejected the common preference model of the household. Using a policy change in Britain where child allowance was transferred from the husband to the wife as a natural experiment, Lundberg, Pollack and Wales (1996) show that an exogenous shock to wife's income altered household expenditures towards "women's clothing" and "children's clothing" at the expense of "men's clothing" and "tobacco and alcohol." The exogenous shift in relative incomes altered the bargaining position of the wife and shifted household expenditures towards goods reflecting her preferences. Bobonis (2009) also finds that cash transfers to the wife in the Mexican Progressa program shifted expenditures towards children's goods. In this section, we 
examine changes in household expenditure patterns to see if bargaining position of married women increased to reflect the increase in their relative earnings.

We use two rounds of the Mexican Household Income and Expenditure Survey (ENIGH), 1992 and 2000. Our sample consists of married households with children where the husband and the wife are between 18 and 54 years old. Different households are interviewed in each round, thus we are unable to follow the same household over time. Households report total expenditures as well as expenditures in various categories covering the third quarter of the year previous to the survey. We deflate expenditures by the national consumer price index published by the Bank of Mexico with 2000 as the base year. We divide by total expenditures to obtain shares and run the following OLS regression:

$$
\text { Share }_{i t}^{k}=\alpha+\beta_{1} \text { Kids__oung }_{i t}+\beta_{2} \text { Kids__old }_{i t}+\beta_{3} \text { Kids }_{i t}+\beta_{4} \text {Tot }_{\exp }+\delta_{t}+u_{i t}
$$

where $\operatorname{Share}_{i t}^{k}$ refers to expenditure share of good $k$ in total expenditures for household $i$ in year $t$. We also control for total expenditures, number of children younger than 3 , number of children aged 3-5 and total number of children. The year dummies in the above regression indicate whether expenditure share of good $k$ increased in 2000 relative to 1992.

Results are reported in table 9. The coefficients on the 2000 year dummy indicate that expenditures on male clothing fell over time while expenditures on female clothing increased. The survey only reports expenditures on "infant and toddler clothing." Expenditures in this category fell over time. "Education" expenditures which are typically associated with female preference increased while "alcohol and tobacco," associated with male preference, fell over time. The bottom three rows investigate the change in the ratio of expenditures. Children's 
clothing fell relative to male clothing if we include families with older children where clothing may be handed down from older siblings. When we look at families with young children only, we find no significant change in the ratio of children's to male clothing. The ratio of female to male clothing, however, increased from 1992 to 2000. The table offers suggestive evidence that women's bargaining power within the household improved along with their relative earnings over the 1990s. Household expenditures shifted from goods associated with male preference, such as men's clothing and tobacco and alcohol, to those associated with female preference such as education and women's clothing.

\section{Conclusion}

Some view rising wage and income inequality in Latin America as an unacceptable consequence of following more efficient market-oriented policies. The impact of trade liberalization and foreign direct investment on domestic wage structure, therefore, is of central policy concern. The evidence in this paper suggests that rather than immiserizing women, trade liberalization improved women's labor market outcomes. Particularly during the reform period, 1990 to 2000, the gender wage ratio increased while employment of women increased. This suggests that the relative demand for women must have increased over this period. We find that both between and within-industry shifts favored female workers. With regards to betweenindustry shifts, we find that tariff reductions expanded industries which were initially female intensive. With regards to within-industry shifts, we find that declines in export tariffs are positively associated with increased hiring of women in skilled blue-collar occupations. This suggests that the exports and technology channel emphasized by recent papers to explain skill premiums (Yeaple (2005), Verhoogen (2008), and Bustos (2011)) may be as important for 
explaining gender outcomes. Finally, the increased earnings power of women appears to have translated into increased bargaining power within the household. Examining household expenditure data, we find that expenditures shifted from male-oriented goods such as male clothing and tobacco and alcohol to female-oriented goods such as women's clothing and children's education. 


\section{References}

Acemoglu, D. Autor, D. and D. Lyle (2004) "Women, War, and Wages: The Effect of Female Labor Supply on the Wage Structure at Midcentury," Journal of Political Economy, 112(3): 495-551.

Amiti, Mary and Jozef Konings (2007), "Trade Liberalization, Intermediate Inputs, and Productivity: Evidence from Indonesia,” American Economic Review, 97(5): 1611-1638.

Artecona, Raquel, and Wendy Cunningham (2002), "Effects of Trade Liberalization on the Gender Wage Gap in Mexico," Working Paper, The World Bank.

Attanasio, O., Pinelopi Goldberg, and Nina Pavcnik (2004), "Trade Reforms and Wage Inequality in Colombia," Journal of Development Economics, 74:331-366.

Autor, D., and Larry Katz (1999), "Changes in the Wage Structure and Earnings Inequality," Ashenfelter, Orley; Card,David, eds. Handbook of Labor Economics, Volume 3A New York: North-Holland.

Becker, Gary (1957), The Economics of Discrimination. Chicago: The University of Chicago Press.

Berman, E., Bound, J., and Z.Griliches (1994) "Changes in the Demand for Skilled Labor Within U.S. Manufacturing: Evidence from the Annual Survey of Manufacturers," Quarterly Journal of Economics, 109: 367-398.

Bernard, A. and J. Bradford Jensen (1999), "Exceptional Exporter Performance: Cause, Effect, or Both?" Journal of International Economics, 47(1): 1-25.

Black, Sandra, and Elizabeth Brainerd (2002), "Importing Equality? The Impact of Globalization on Gender Discrimination,” NBER Working Paper 9110.

Bobonis, Gustavo (2009), "Is Allocation of Resources within the Household Efficient? New Evidence from a Randomized Experiment," Journal of Political Economy, 117: 453-503.

Bound, J. and G. Johnson (1992), "Changes in the Structure of Wages in the 1980s: An Evaluation of Alternative Explanations," American Economic Review, 82: 271-392.

Brown, C., Pagan, Jose, and E. Rodriguez-Oreggia (1999), "Occupational Attainment and Gender Earnings Differentials in Mexico," Industrial and Labor Relations Review, 53(1):123-135.

Bussolo, Maurizio, R. De Hoyos. (2009), "Introduction and Overview.” Bussolo, M. and R. De Hoyoy, ed. Gender Aspects of the trade and Poverty Nexus. Washington, DC: World Bank Press. 
Bustos, Paula (2011), “The Impact of Trade on Technology and Skill Upgrading: Evidence from Argentina," Working paper.

Duflo, Esther (2000), "Grandmothers and Granddaughters: Old Age Pension and IntraHousehold Allocation in South Africa," NBER Working Paper, No. 8061.

Duflo, Esther (forthcoming), “Women's Empowerment and Economic Development,” Journal of Economic Literature.

Ederington, J., J. Minier, and K. Troske (2010), "Where the Girls Are: Trade and Labor Market Segregation in Colombia," Working Paper.

Feenstra, Robert, John Romalis, and Peter Schott (2002), “U.S. Imports, Exports, and Tariff Data, 1989-2001,” NBER Working Paper, No. 9387.

Galor, Oded and David N. Weil (1996). "The Gender Gap, Fertility, and Growth.” American Economic Review, 86 (3): 374-387.

Goldberg, P., A. Khandelwal, N. Pavcnik, and P. Topalova (2010), "Imported Intermediate Inputs and Domestic Product Growth: Evidence from India," Quarterly Journal of Economics, 125(4): 1727-1767.

Hanson, Gordon, and Ann Harrison (1999), “Trade and Wage Inequality in Mexico,” Industrial Labor Relations Review, 52(2): 271-288.

Iacovone, Leonardo, and Beata Javorcik (2010), "Multi-Product Exporters: Product churning, Uncertainty and Export Discoveries,” The Economic Journal, 120: 481-499.

Juhn, Chinhui, Gergely Ujhelyi, and Carolina Villegas-Sanchez (2012), "Men, Women, and Machines: How Trade Impacts Gender Inequality,” NBER Working Paper 18106.

Katz, Lawrence, and Kevin M. Murphy (1992), “Changes in Relative Wages, 1963-1987: Supply and Demand Factors," Quarterly Journal of Economics, 107(1): 35-78.

Lundberg, Shelly, R. Pollak and T. Wales (1997). "Do Husbands and Wives Pool Resources? Evidence from the UK Child Beneft," Journal of Human Resources, 32: 463-479.

Melendez, Jorge. (2001) "The Structure of Wages under Trade Liberalization: Mexico from 1984 to 1998," Ph..D. Dissertation, University of Chicago.

Melitz, Marc (2003), "The Impact of Trade on Intra-Industry Reallocations and Aggregate Industry Productivity,” Econometrica, 71(6): 1695-1725.

Oostendorp, Remco (2004), "Globalization and the Gender Wage Gap," Working Paper, Free University, Amsterdam. 
Pagan, Jose A. and Miren Ullibarri (2000), "Group Heterogeneity and the Gender Earnings Gap in Mexico", Economia Mexicana. Nueva Epoca. Vol. IX, No. 1

Qian, Nancy (2008) "Missing Women and the Price of Tea in China: The Effect of Sex-Specific Earnings on Sex Imbalance,” Quarterly Journal of Economics, 123(3): 1251-1285.

Rendall, Michelle (2010), "Brain versus Brawn: The Realization of Women's Comparative Advantage," working paper, University of Zurich.

Revenga, Ana L. (1997), "Employment and Wage Effects of Trade Liberalization: The Case of Mexican Manufacturing," Journal of Labor Economics; 15(3): S20-43.

Sanchez, Susana M. and Jose A. Pagan (2001), "Explaining Gender Differences in Earnings in the Microenterprise Sector", in Maria Correia and Elizabeth Katz (eds.) The Economics of Gender in Mexico: Work, Family, State and Market.

Thomas, Duncan (1990) "Intra-Household Resource Allocation: An Inferential Approach," Journal of Human Resources, 35: 635-654.

United Nations (2009), UN Millennium Development Goals Report 2009, New York: United Nations.

Verhoogen, Eric (2008), “Trade, Quality Upgrading, and Wage Inequality in the Mexican Manufacturing Sector,” Quarterly Journal of Economics, 123 (2): 489-530.

Weinberg, Bruce (2000), “Computer Use and the Demand for Female Workers," Industrial and Labor Relations Review,Vol. 53, No.2, pp.290-307.

Welch, Finis (2000), “Growth in Women's Relative Wages and in Inequality Among Men: One Phenomenon or Two?” American Economic Review, 90(2): 444-449.

Yeaple, Stephen (2005), “A Simple Model of Firm Heterogeneity, International Trade, and Wages," Journal of International Economics, 65(1): 1-20.

Zabludovsky, J. (2005), "El Tlcan y La Politica de Comercio Exterior en Mexico: Una Agenda Inconclusa,” Informacion Comercial Espanola (821): 59-70. 


\section{Data Appendix}

\section{A. Household Surveys (Census, ENIGH)}

We use data from 9 rounds of the Household Income and Expenditure Surveys (ENIGH), a nationally representative survey which spans the period 1984-2004. We also use data from the 10\% samples of the Mexican Population Census of 1990 and 2000 available from the Census IPUMS. Unlike the ENIGH, statistical inferences using the larger Census samples are significant at the two-digit industry level (92 categories) and at the state level (32 states). Appendix Table 1 provides summary statistics of the data.

For calculating wages we construct a wage sample consisting of men and women who are 15-64 years old, who worked at least 30 hours during the survey week and reported no selfemployment income. Wages are reported wage and salary earnings last month converted to a weekly wage by dividing by 4.33 . Earnings were deflated by the national consumer price index published by the Bank of Mexico with 2000 as the base year.

For reporting quantities of labor by education and by industry, we construct a sample of 15-64 year olds who report positive hours during the survey week, including the self-employed. We report hours-weighted employment shares and employment shares in efficiency units of labor. To calculate efficiency units of labor, we first calculate average wages (fixed across all years) by 2 gender, 10 age and 6 education categories. We weight hours by these average wages to calculate efficiency units of labor. All our calculations are weighted by the household weights to make the sample nationally representative. 


\section{B. Data on Tariffs, Exports, and Imports}

We match industry classifications available in the 1990 and 2000 Census samples to the Sistema de Clasificacion Industrial de America del Norte 1997 (SCIAN97 and also called the NAICS in the U.S.). Tariff, export, and import data for 1993-2000 were obtained from the Ministry of the Economy (formerly SECOFI), international trade statistics (www.economia.gob.mx). Tariffs, exports and imports are reported in "facciones arancelarias" which is a classification system for products. There are more than 34,000 products. For tariff schedules we used the book Fracciones Arancelarias y Plazos de Desgravación, Tratado de Libre Comercio de América del Norte (1994), published by the Ministry of Economy. The book publishes each product with the 1993 tariff rates $(0,5,10,15,20 \%)$ along with a code, A, B, C, D or B6 which describes the rate at which the tariff is reduced to zero. For example, Code A corresponds to a tariff which is reduced to zero in 1994. We aggregated products and tariff schedules up to the SCIAN97 industry codes using the 1993 import shares as weights. U.S tariff data come from John Romalis (http://faculty.chicagobooth.edu/john.romalis/more/) with the description and documentation available in the NBER Working paper 9387. We aggregate the 6 digit harmonized tariff schedules available in the Romalis data up to the 3-digit SCIAN97 categories using the 1993 shares of Mexican exports to the U.S. These matched tariff data are available from the authors upon request.

\section{Establishment Surveys (ENESTyC)}

The establishment-level data come from Encuesta Nacional de Empleo, Salarios, Tecnologia y Capacion (ENESTyC). The samples in ENESTyC are representative cross sections of 
establishments in the manufacturing sector for the years 1992, 1998, and 2001. We use the 1992 and 2001 samples in our analysis which refer to the years 1991 and 2000. We drop micro establishments (those with 15 employees or less) from the analysis since these smaller establishments were oversampled in 2001 but we do not have clear details of the oversampling. "Value added" is defined as the value of output minus materials. We deflate output by the producer price index (PPI) at the industry level and materials by the materials price index (MPI) provided by the Central Bank of Mexico. Wage bills are deflated by the consumer price index (CPI). "Capital" is value of total assets deflated by PPI. "R\&D Share" refers to share of income devoted to research and development. To construct female wage bill share, we first aggregate wage bills of workers in different white and blue collar categories, supervisors, clerical workers, special production workers, and general production workers, all of which are reported separately by gender. Some categories have missing values in which case we replace with zeros before adding. The wage bill shares refer to basic salary for full time workers and exclude payment for extra hours or contributions to social security. We also exclude part time workers, hourly employees, and subcontractors from wage bill calculations. "Foreign" refers to establishments where 10 percent or more of the assets are foreign-owned. "Exporter" refers to establishments with positive exports. "Foreign exporter" refers to establishments which fulfill both conditions. 
Figure 1

Effective Tariffs, 1980-2004

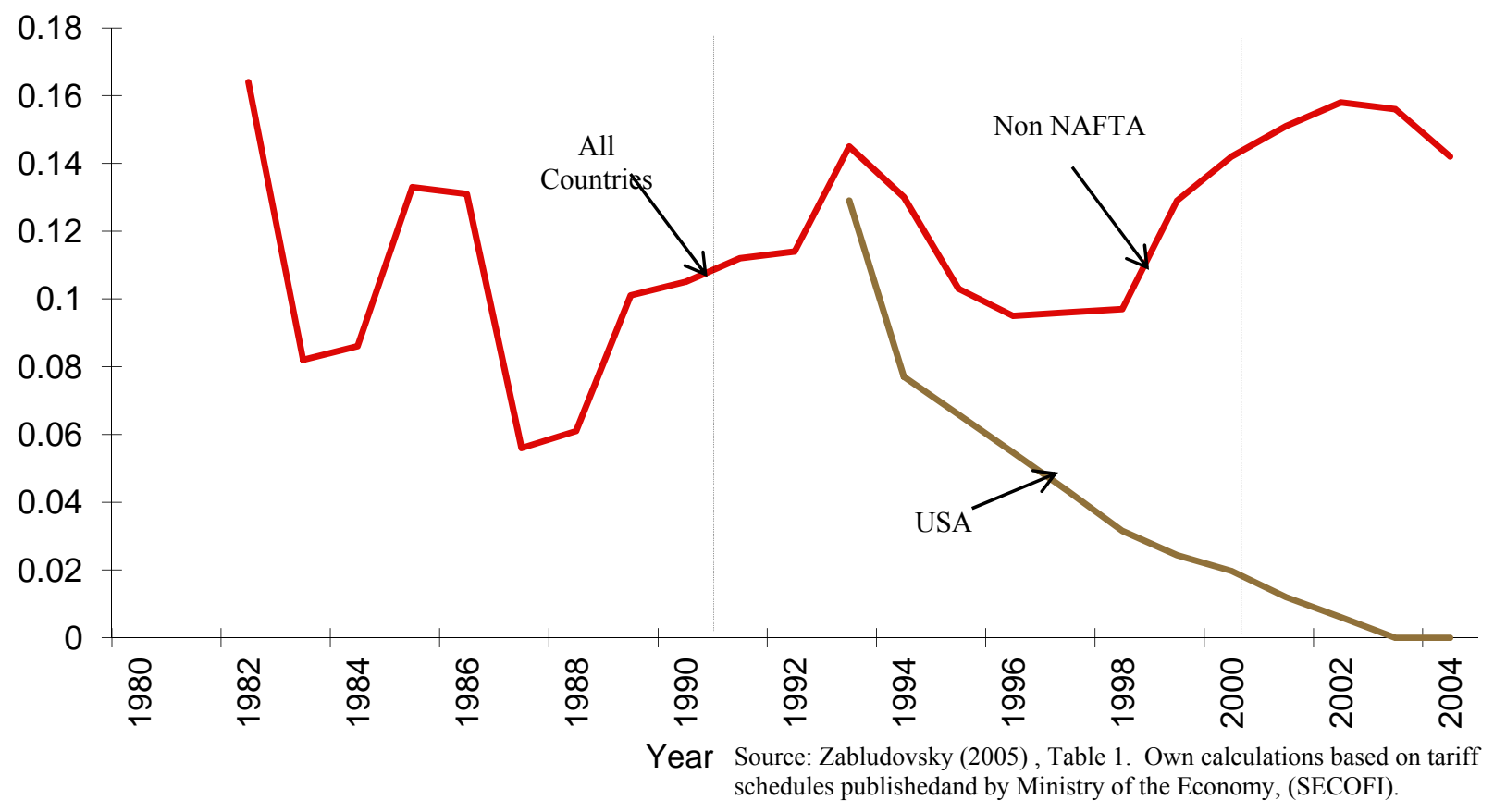

Figure 2

Non-oil Exports and Imports as share of GDP, 1980-2004

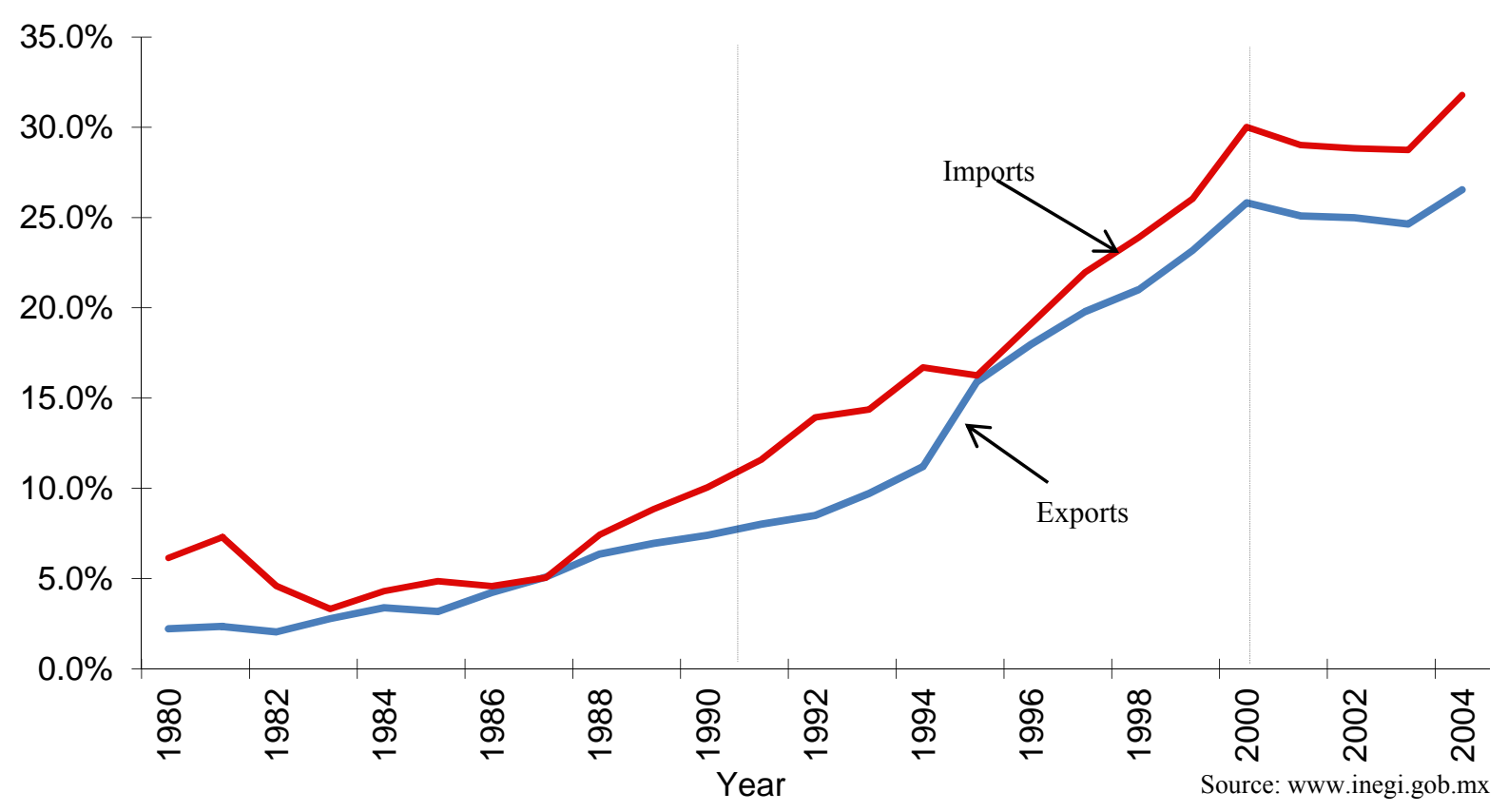


Table 1

\section{Tariff Rates Pre and Post-NAFTA}

\begin{tabular}{|c|c|c|c|c|}
\hline & \multicolumn{2}{|c|}{ Mexico } & \multicolumn{2}{|c|}{ U.S. } \\
\hline & 1993 Rate & Change & 1993 Rate & Change \\
\hline & $\%$ & 1993-00 & $\%$ & 1993-00 \\
\hline Industry & (1) & $(2)$ & (3) & (4) \\
\hline Agriculture & 4.5 & -3.8 & 4.1 & -3.6 \\
\hline Livestock & 4.5 & -3.2 & 0.0 & 0.0 \\
\hline Fish & 0.0 & 0.0 & 0.0 & 0.0 \\
\hline Oil and Gas & 10.0 & -7.0 & 0.5 & -0.5 \\
\hline Minerals & 6.1 & -5.9 & 0.3 & -0.3 \\
\hline Food & 12.4 & -9.1 & 3.6 & -2.0 \\
\hline Beverage and Tobacco & 18.9 & -14.4 & 3.7 & -3.2 \\
\hline Textiles and Fabrics & 12.9 & -10.0 & 13.2 & -13.1 \\
\hline Textile Mill Products & 19.3 & -14.4 & 6.1 & -6.0 \\
\hline Clothing & 20.0 & -17.1 & 13.2 & -12.9 \\
\hline Leather & 9.3 & -7.6 & 11.6 & -8.8 \\
\hline Wood & 17.5 & -14.4 & 1.2 & -1.1 \\
\hline Paper & 8.3 & -6.2 & 0.0 & 0.0 \\
\hline Printed Matters & 9.0 & -8.1 & 0.0 & 0.0 \\
\hline Petroleum and Coal Products & 1.9 & -1.4 & 1.5 & -1.1 \\
\hline Chemicals & 9.4 & -7.8 & 1.8 & -1.6 \\
\hline Plastics and Rubber & 15.2 & -11.5 & 1.2 & -1.0 \\
\hline Nonmetallic Mineral Products & 14.9 & -12.5 & 4.7 & -1.8 \\
\hline Primary Metal & 8.8 & -6.5 & 3.2 & -2.6 \\
\hline Fabricated Metal & 13.8 & -12.1 & 0.5 & -0.5 \\
\hline Machinery, Except Electrical & 14.6 & -13.9 & 0.0 & 0.0 \\
\hline Computers and Electronics & 12.8 & -12.0 & 1.7 & -1.7 \\
\hline Electrical Equip \& Appliances & 14.0 & -10.9 & 0.2 & -0.2 \\
\hline Transportation Equip & 11.4 & -8.9 & 1.3 & -1.3 \\
\hline Furniture & 16.1 & -11.9 & 0.0 & 0.0 \\
\hline Miscellaneous & 15.3 & -14.0 & 0.8 & -0.8 \\
\hline
\end{tabular}

Source: Mexican tariff data, Fracciones Arancelarias y Plazos de Desgravacion, Tratado de Libre Comericio de America del Norte, 1994. U.S. tariff data, from Romalis (2002). For both The U.S. tariff data we begin with 8-digit harmonized tariff system categories and aggregate up 3-digit SCIAN97 (NAICS) categories using initial import and export shares as weights. Details of the data construction are in the data appendix. 
Figure 3a. Female/Male Mean Weekly Wage Ratio

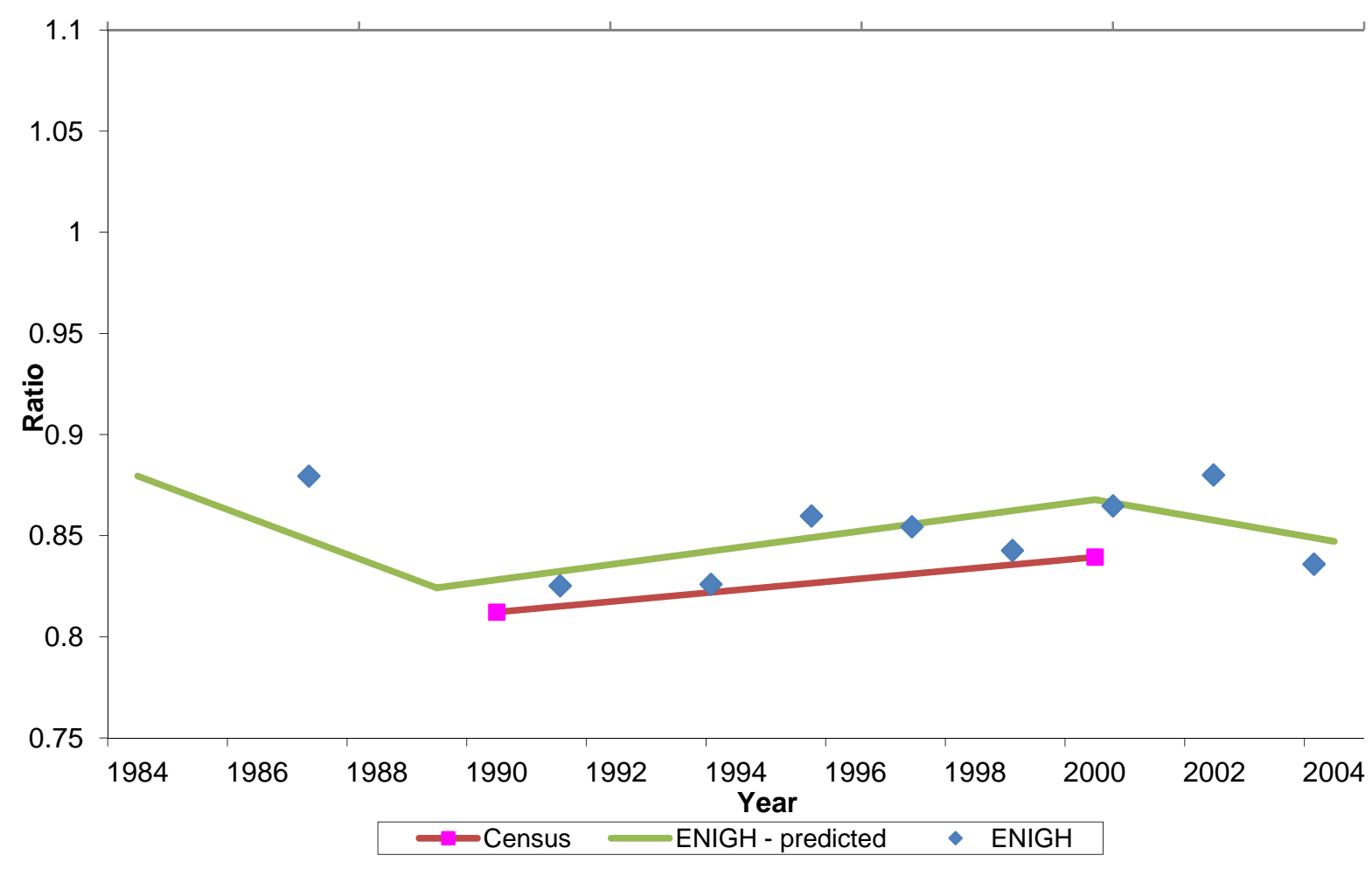

Figure 3b. Female/Male Mean Weekly Wage Ratio Composition Fixed

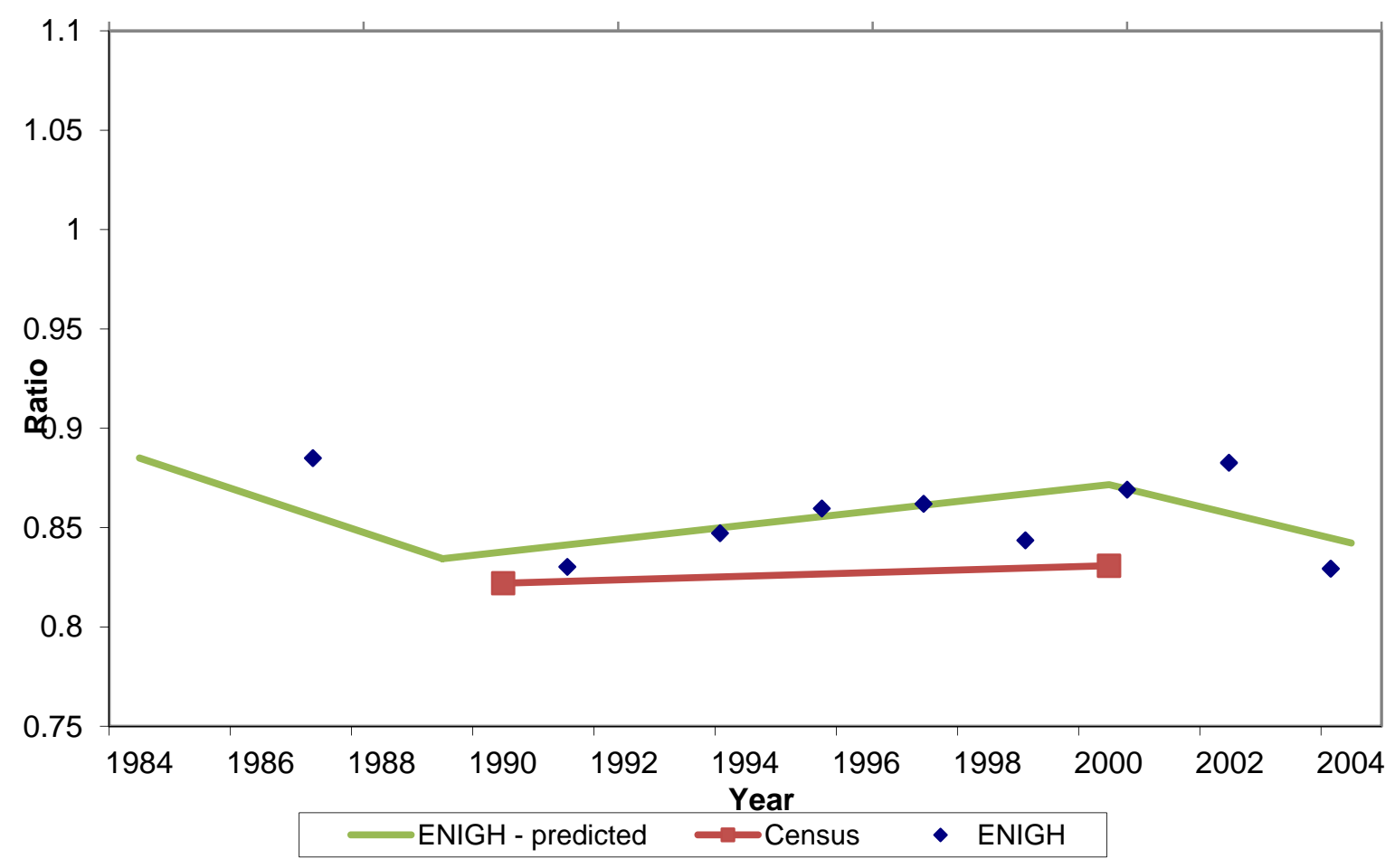


Figure 3c. Female/Male Mean Weekly Wage Ratio Including Self-Employed

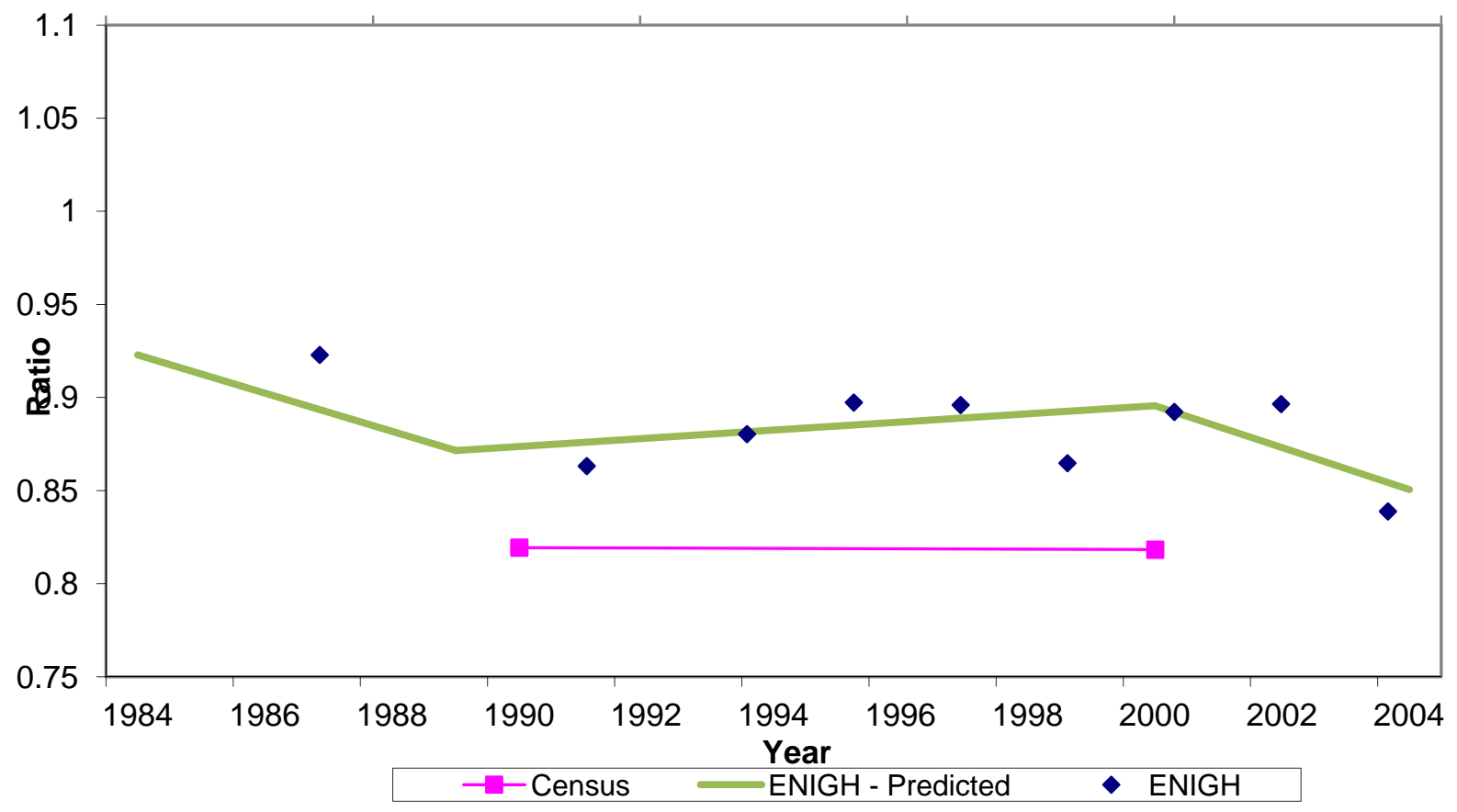

Figure 3d. Female/Male Mean Hourly Wage Ratio Including Self-Employed

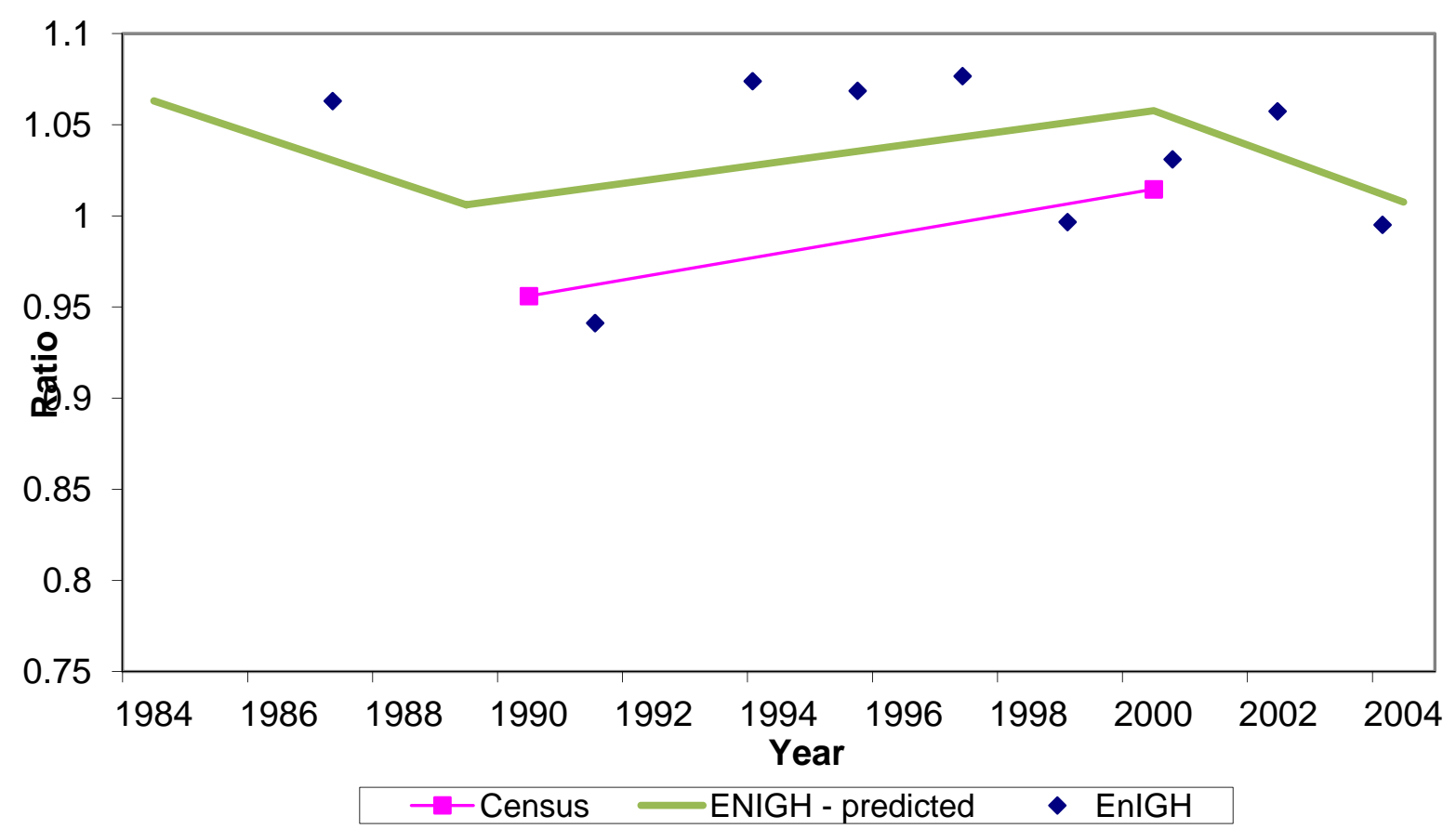




\begin{tabular}{|c|c|c|c|c|c|c|c|c|c|}
\hline Table 2 & & & & & & & & & \\
\hline \multicolumn{10}{|c|}{ Employment-Population Ratio 15-64 Year Old Women } \\
\hline & \multicolumn{9}{|c|}{ Year } \\
\hline & 1984 & $1989 / 90$ & 1992 & 1994 & 1996 & 1998 & 2000 & 2002 & 2004 \\
\hline \multicolumn{10}{|l|}{ ENIGH } \\
\hline$<12$ & 0.255 & 0.263 & 0.290 & 0.337 & 0.375 & 0.394 & 0.387 & 0.412 & 0.395 \\
\hline$>=12$ & 0.421 & 0.498 & 0.502 & 0.530 & 0.562 & 0.562 & 0.525 & 0.559 & 0.580 \\
\hline All & 0.267 & 0.289 & 0.315 & 0.363 & 0.402 & 0.419 & 0.412 & 0.440 & 0.441 \\
\hline \multicolumn{10}{|l|}{ Census } \\
\hline$<12$ & & 0.166 & & & & & 0.294 & & \\
\hline$>=12$ & & 0.478 & & & & & 0.541 & & \\
\hline \multirow[t]{3}{*}{ All } & & 0.211 & & & & & 0.348 & & \\
\hline & & & & & & & & & \\
\hline & & & & & & & & & \\
\hline \multicolumn{10}{|c|}{ Employment-Population Ratio 15-64 Year Old Men } \\
\hline & \multicolumn{9}{|c|}{ Year } \\
\hline & 1984 & $1989 / 90$ & 1992 & 1994 & 1996 & 1998 & 2000 & 2002 & 2004 \\
\hline \multicolumn{10}{|l|}{ ENIGH } \\
\hline$<12$ & 0.791 & 0.795 & 0.817 & 0.827 & 0.817 & 0.842 & 0.846 & 0.832 & 0.816 \\
\hline$>=12$ & 0.658 & 0.763 & 0.770 & 0.798 & 0.802 & 0.800 & 0.819 & 0.779 & 0.820 \\
\hline All & 0.774 & 0.790 & 0.809 & 0.821 & 0.814 & 0.832 & 0.840 & 0.819 & 0.817 \\
\hline \multicolumn{10}{|l|}{ Census } \\
\hline$<12$ & & 0.727 & & & & & 0.774 & & \\
\hline$>=12$ & & 0.762 & & & & & 0.816 & & \\
\hline All & & 0.733 & & & & & 0.784 & & \\
\hline
\end{tabular}

Source: ENIGH 1984-2004, Census 1990, 2000. Sample includes 15-64 year old males and females. Employment is defined as those with positive hours of work during the survey week. 
Table 3

\begin{tabular}{|c|c|c|c|c|c|c|c|c|c|}
\hline \multicolumn{10}{|c|}{ ENIGH - Female Labor as a Share of Total Labor } \\
\hline & \multicolumn{9}{|c|}{ Year } \\
\hline & 1984 & 1989 & 1992 & 1994 & 1996 & 1998 & 2000 & 2002 & 2004 \\
\hline \multicolumn{10}{|l|}{ A. Hours } \\
\hline$<12$ Years & 0.215 & 0.238 & 0.247 & 0.269 & 0.293 & 0.300 & 0.303 & 0.310 & 0.312 \\
\hline$>=12$ Years & 0.232 & 0.273 & 0.275 & 0.301 & 0.316 & 0.321 & 0.316 & 0.349 & 0.387 \\
\hline All & 0.217 & 0.244 & 0.252 & 0.274 & 0.298 & 0.304 & 0.306 & 0.319 & 0.333 \\
\hline \multicolumn{10}{|c|}{ B. Efficiency Units } \\
\hline$<12$ Years & 0.195 & 0.223 & 0.229 & 0.251 & 0.270 & 0.278 & 0.289 & 0.295 & 0.291 \\
\hline$>=12$ Years & 0.177 & 0.211 & 0.219 & 0.240 & 0.262 & 0.261 & 0.247 & 0.285 & 0.321 \\
\hline All & 0.190 & 0.219 & 0.225 & 0.246 & 0.266 & 0.271 & 0.270 & 0.290 & 0.306 \\
\hline \multicolumn{10}{|c|}{ C.Wage Bill Shares } \\
\hline$<12$ Years & 0.209 & 0.221 & 0.230 & 0.249 & 0.266 & 0.282 & 0.285 & 0.292 & 0.279 \\
\hline$>=12$ Years & 0.174 & 0.211 & 0.223 & 0.233 & 0.267 & 0.254 & 0.241 & 0.311 & 0.327 \\
\hline All & 0.201 & 0.218 & 0.227 & 0.242 & 0.266 & 0.270 & 0.265 & 0.301 & 0.303 \\
\hline
\end{tabular}

Sample includes 15-64 year old males and females. The table reports the female shares of total labor measured in hours, in efficiency units of labor, and in wage bill shares. To calculate shares in efficiency units, we weight hours by the group specific average wage, fixed over years. With wage bill shares, average wages by group vary by year.

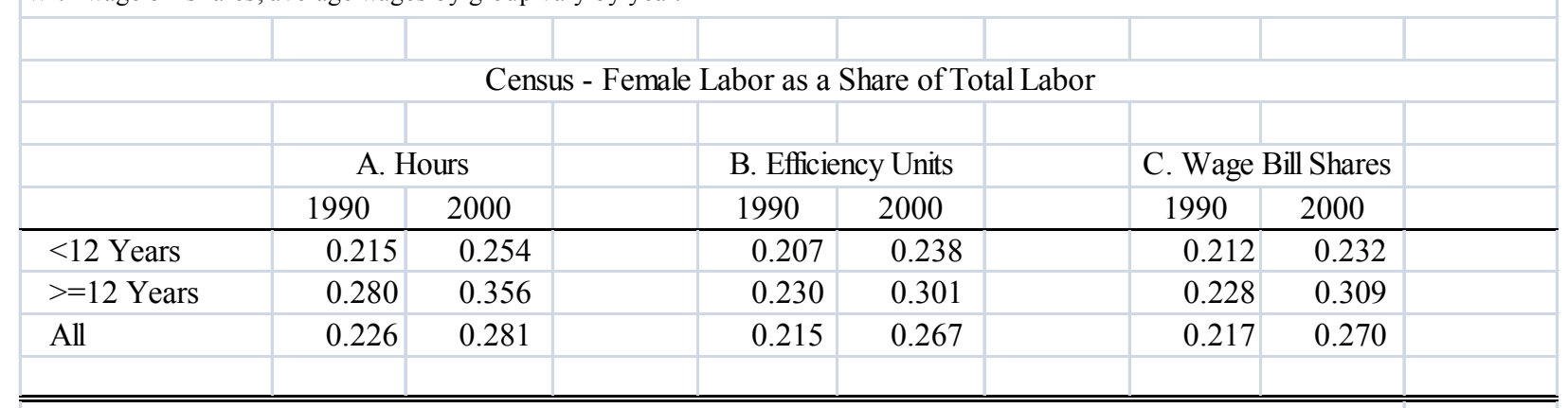

Sample includes 15-64 year old males and females. The table reports the female shares of total labor measured in hours, in efficiency units of labor, and in wage bill shares. To calculate shares in efficiency units, we weight hours by the group specific average wage, fixed over years. With wage bill shares, average wages by group vary by year. 


\begin{tabular}{|c|c|c|c|c|}
\hline \multicolumn{5}{|l|}{ Table 4} \\
\hline \multicolumn{5}{|c|}{ Indus trial Distribution (Census) } \\
\hline \multirow{2}{*}{ Industry (SCIAN97) } & \multicolumn{2}{|c|}{ Year } & & \\
\hline & 1990 & 2000 & \multicolumn{2}{|c|}{ Female Share in $1990(\%)$} \\
\hline Agriculture & 12.5 & 7.7 & 2.9 & \\
\hline Fishing & 2.5 & 1.8 & 3.6 & \\
\hline Oil and Gas & 1.3 & 0.8 & 9.0 & \\
\hline Electricity and Water & 1.0 & 0.7 & 9.7 & \\
\hline Construction & 5.8 & 7.9 & 1.8 & \\
\hline Light Manufacturing & 7.2 & 7.0 & 25.7 & \\
\hline Medium Manufacturing & 4.9 & 4.1 & 14.4 & \\
\hline Heavy Manufacturing & 6.6 & 7.1 & 14.4 & \\
\hline Wholesale & 2.2 & 1.6 & 13.8 & \\
\hline Retail & 13.8 & 14.6 & 28.4 & \\
\hline Transportation and Storage & 9.1 & 8.9 & 4.4 & \\
\hline Communications & 1.2 & 1.2 & 25.5 & \\
\hline Financial Services & 2.2 & 1.5 & 29.1 & \\
\hline Real Estate Services & 0.4 & 0.6 & 24.3 & \\
\hline Professional Services & 3.3 & 4.8 & 21.5 & \\
\hline Education & 7.7 & 8.1 & 46.9 & \\
\hline Health Services & 5.3 & 5.1 & 48.4 & \\
\hline Recreation Services & 0.7 & 0.8 & 21.1 & \\
\hline Hotels and Restaurants & 3.6 & 4.5 & 35.4 & \\
\hline Other Services & 3.3 & 5.2 & 62.0 & \\
\hline Government & 5.5 & 6.1 & 21.8 & \\
\hline Total & 100 & 100 & 21.7 & \\
\hline
\end{tabular}

Source: Mexican Census IPUMS, 1990 and 2000. The table reports shares of labor in efficiency units. 


\begin{tabular}{|c|c|c|c|}
\hline Table 5 & & & \\
\hline \multicolumn{4}{|c|}{ Industrial Distribution: Manufacturing (Census) } \\
\hline \multirow{2}{*}{ Industry } & \multicolumn{2}{|c|}{ Year } & \\
\hline & 1990 & 2000 & Female Share in $1990(\%$ \\
\hline Food & 16.4 & 15.3 & 19.3 \\
\hline Beverages and Tobacco & 4.8 & 3.8 & 7.7 \\
\hline Textiles and Fabrics & 3.5 & 2.5 & 12.7 \\
\hline Textile Mill Products & 0.9 & 1.4 & 30.3 \\
\hline Clothing & 8.2 & 11.9 & 55.6 \\
\hline Leather & 5.1 & 3.8 & 21.3 \\
\hline Wood & 1.4 & 1.6 & 5.9 \\
\hline Paper & 1.8 & 1.9 & 11.3 \\
\hline Printing & 4.7 & 2.6 & 19.2 \\
\hline Petroleum and Coal Products & 2.8 & 1.7 & 10.2 \\
\hline Chemicals & 5.7 & 4.6 & 20.3 \\
\hline Plastic and Rubber & 2.6 & 2.5 & 17.7 \\
\hline Nonmetallic Mineral Products & 6.8 & 7.4 & 8.5 \\
\hline Primary Metal & 3.7 & 2.6 & 6.4 \\
\hline Fabricated Metal & 7.0 & 7.1 & 14.1 \\
\hline Machinery, Except Electrical & 2.7 & 2.1 & 7.6 \\
\hline Computers and Electronics & 2.7 & 4.5 & 30.2 \\
\hline Electrical Equip \& Appliances & 4.1 & 3.4 & 32.0 \\
\hline Transportation Equipment & 5.9 & 8.4 & 12.9 \\
\hline Furniture & 6.3 & 6.9 & 5.1 \\
\hline Miscellaneous & 2.7 & 4.0 & 25.1 \\
\hline Total & 100 & 100 & 18.7 \\
\hline
\end{tabular}

Source: Mexican Census IPUMS, 1990 and 2000. The table reports shares of labor in efficiency units. 
Table 6

Change in Share of Workers by Education and Gender, 1990-2000, All Sectors

\begin{tabular}{|l|r|r|r|r|r|r|r|}
\hline \multirow{2}{*}{ Group } & \multicolumn{3}{|c|}{ Employment Share } & \multicolumn{3}{c|}{ Wage Bill Share } \\
\hline & Between & Within & Total & Between & \multicolumn{1}{c|}{ Within } & Total \\
\hline Men $<12$ & -2.39 & -8.59 & -10.98 & -4.15 & -10.38 & -14.53 \\
\hline Women $<12$ & 1.42 & -2.22 & -0.80 & 1.05 & -3.68 & -2.63 \\
\hline Men $>=12$ & 0.73 & 5.04 & 5.77 & 2.04 & 7.23 & 9.28 \\
\hline Women $>=12$ & 0.24 & 5.78 & 6.01 & 1.05 & 6.83 & 7.88 \\
\hline Women & 1.66 & 3.55 & 5.21 & 2.10 & 3.15 & 5.25 \\
\hline
\end{tabular}

Change in Share of Workers by Education and Gender, 1990-2000, Tradeables Only

\begin{tabular}{l|r|r|r|r|r|r|}
\multirow{2}{*}{ Group } & \multicolumn{3}{|c|}{ Employment Share } & \multicolumn{3}{c|}{ Wage Bill Share } \\
\cline { 2 - 8 } & Between & Within & Total & Between & \multicolumn{1}{c|}{ Within } & \multicolumn{1}{c|}{ Total } \\
\hline Men $<12$ & -4.02 & -7.07 & -11.09 & -4.85 & -8.44 & -13.29 \\
\hline Women $<12$ & 2.18 & 0.92 & 3.10 & 1.63 & 0.27 & 1.90 \\
\hline Men $>=12$ & 1.53 & 3.85 & 5.38 & 2.76 & 5.44 & 8.20 \\
\hline Women $>=12$ & 0.31 & 2.31 & 2.62 & 0.46 & 2.73 & 3.19 \\
\hline Women & 2.49 & 3.22 & 5.71 & 2.09 & 2.60 & 5.09 \\
\hline
\end{tabular}

Change in Share of Workers by Education and Gender, 1990-2000, Manufacturing Only

\begin{tabular}{|l|r|r|r|r|r|r|}
\hline \multirow{2}{*}{ Group } & \multicolumn{3}{|c|}{ Employment Share } & \multicolumn{3}{c|}{ Wage Bill Share } \\
\cline { 2 - 8 } & Between & Within & Total & Between & Within & Total \\
\hline Men $<12$ & -2.00 & -7.83 & -9.83 & -2.57 & -8.94 & -11.51 \\
\hline Women $<12$ & 1.99 & 0.07 & 2.06 & 1.08 & -0.71 & 0.37 \\
\hline Men $>=12$ & -0.12 & 4.42 & 4.30 & 1.17 & 6.13 & 7.30 \\
\hline Women $>=12$ & 0.12 & 3.34 & 3.46 & 0.33 & 3.52 & 3.84 \\
\hline Women & 2.11 & 3.41 & 5.53 & 1.40 & 2.10 & 4.21 \\
\hline \hline
\end{tabular}

Source: Mexican Census IPUMS 1990 abd 2000. The panel is based on 69 industries, the middle panel is bas ed on 28 industries, and the bottom panel is based on 21 industries. Employment shares are reported in efficiency units. 

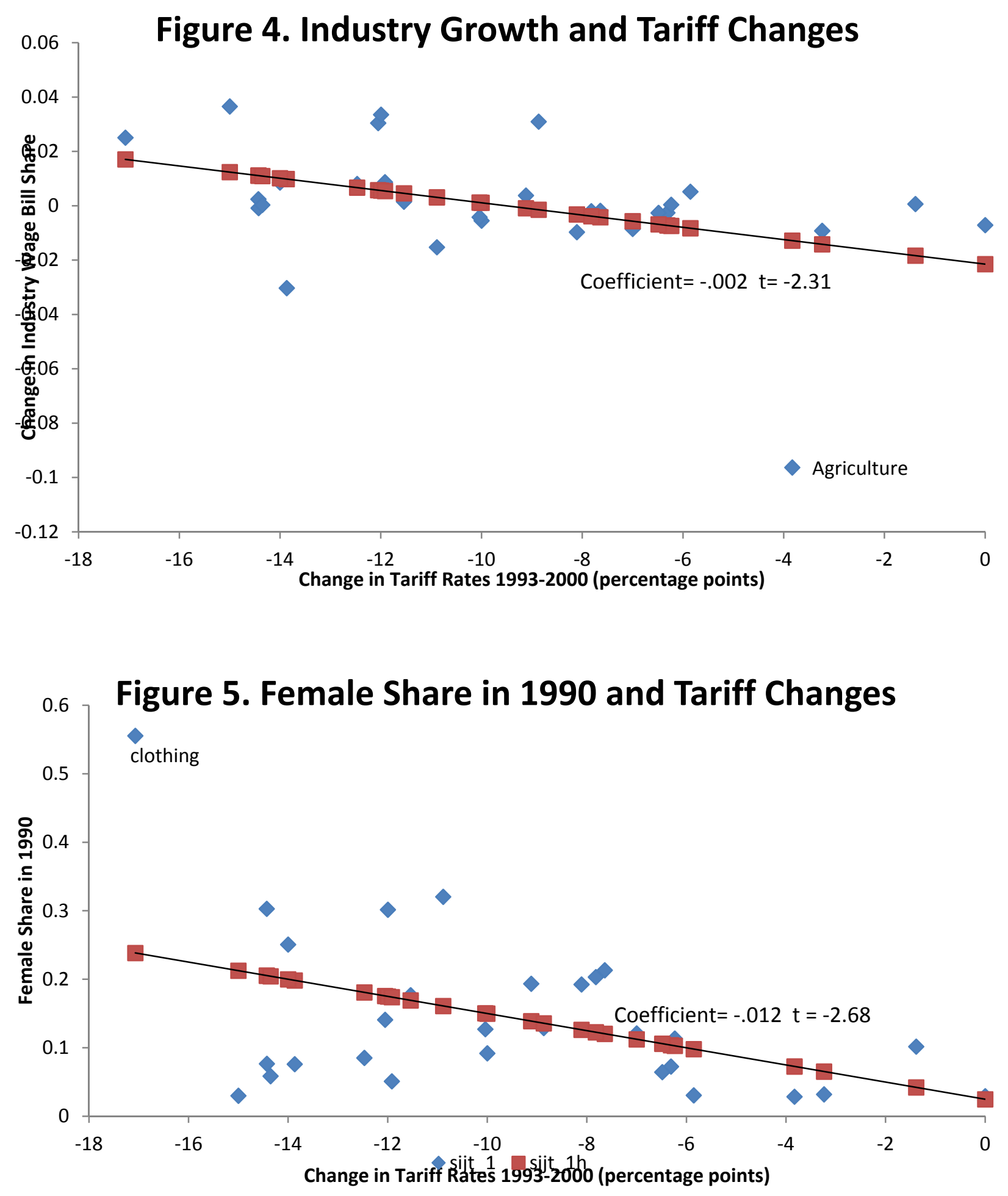


\begin{tabular}{|c|c|c|c|c|c|c|}
\hline Table 7 & & & & & & \\
\hline \multirow{2}{*}{\multicolumn{7}{|c|}{ Summary Statistics - Establishment Survey (ENESTyC) }} \\
\hline & & & & & & \\
\hline & \multicolumn{3}{|c|}{1991} & \multicolumn{3}{|c|}{2000} \\
\hline Variable & $\mathrm{N}$ & Mean & Std & $\mathrm{N}$ & Mean & Std \\
\hline Log (Capital/ Value Added) & 4151 & -0.38 & 1.41 & 5272 & -0.52 & 1.68 \\
\hline Log Value Added & 4151 & 10.61 & 1.70 & 5272 & 10.31 & 1.96 \\
\hline R\&D/Income & 4238 & 0.01 & 0.02 & 4848 & 0.00 & 0.01 \\
\hline Share of White Collar Workers & 4238 & 0.29 & 0.17 & 5654 & 0.28 & 0.19 \\
\hline Foreign Ownership ( $>=10 \%)$ & 4238 & 0.23 & 0.42 & 5037 & 0.24 & 0.43 \\
\hline Exports $>0$ & 4238 & 0.43 & 0.50 & 5570 & 0.55 & 0.50 \\
\hline Foreign Exporter & 4238 & 0.17 & 0.38 & 4975 & 0.21 & 0.50 \\
\hline Share of Foreigned Owned Assets & 4238 & 0.19 & 0.37 & 5037 & 0.21 & 0.39 \\
\hline Exports as Share of Sales & 4238 & 0.20 & 0.36 & 5570 & 0.22 & 0.34 \\
\hline Export Share*Foreign Share & 4238 & 0.09 & 0.27 & 4975 & 0.12 & 0.29 \\
\hline Maquila & 4238 & 0.09 & 0.29 & 5654 & 0.10 & 0.30 \\
\hline & & & & & & \\
\hline & & & & & & \\
\hline
\end{tabular}

Source: Encuesta Nacional de Empleo, Salarios, Tecnologia y Capacitacion (ENESTyC) survey 1991 and 2001. The table reports means for establishments with more than 15 employees. 
Table 8 - Female Wage Bill Share and Tariffs - Establishment Data

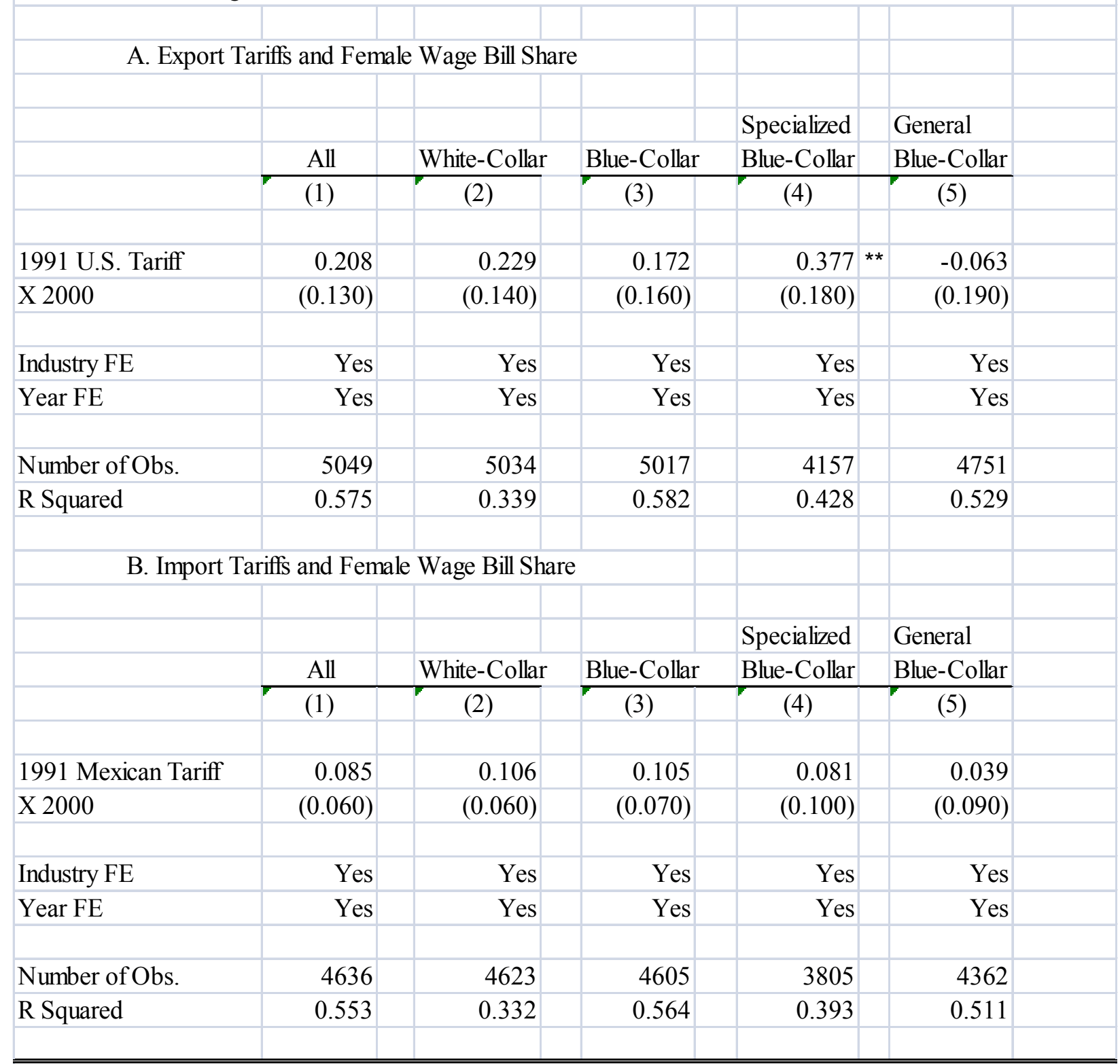

Source: ENESTyC. Standard errors in parentheses; ***significant at 1 percent level; ** significant 5 percent level; * significant at 10 percent level. The dependent variable for column (1) is female wage bill share, for column (2) female wage bill share in white-collar jobs, for column (3) female wage bill share in blue-collar jobs, for column (4) female wage bill share in specialized blue-collar jobs, and for column (5) female wage bill share in general blue collar jobs. The sample includes firms with at least one female employee. Small firms with less than 100 employees, maquiladoras, and firms with more than $50 \%$ of income earned from maquiladoras are excluded. Additional controls in the regression include age of firm, age squared, $\log (\mathrm{Capita} / \mathrm{Value}$ Added), $\log$ (Value Added), R\&D expenditures as share of total income, share of white-collar workers, dummy for at least 10 percent of capital that is foreign. 
Table 9

Expenditure Shares 1992 and 2000 - Married Couples with Children

\begin{tabular}{|c|c|c|c|c|}
\hline & $(1)$ & (2) & (3) & \\
\hline & & & 2000 Dummy & \\
\hline & 1992 & 2000 & with Controls & \\
\hline Total Expenditures (2000 Pesos) & 4683.4 & 4470.3 & & \\
\hline \multirow[t]{2}{*}{ Male Clothing } & 0.0263 & 0.0244 & -0.0014 & $* *$ \\
\hline & & & $(0.0006)$ & \\
\hline \multirow[t]{2}{*}{ Female Clothing } & 0.0112 & 0.0141 & 0.0035 & $* *$ \\
\hline & & & $(0.0004)$ & \\
\hline \multirow[t]{2}{*}{ Child Clothing (only young children) } & 0.0117 & 0.0039 & -0.0038 & $* *$ \\
\hline & & & $(0.0011)$ & \\
\hline \multirow[t]{2}{*}{ Education } & 0.0678 & 0.0770 & 0.0061 & $* *$ \\
\hline & & & $(0.0019)$ & \\
\hline \multirow[t]{2}{*}{ Alcohol and Tobacco } & 0.0112 & 0.0058 & -0.0049 & ** \\
\hline & & & $(0.0005)$ & \\
\hline Child Clothing/Male Clothing & & & -0.3629 & ** \\
\hline (with older children) & & & $(0.0466)$ & \\
\hline Child Clothing/Male Clothing & & & -0.0228 & \\
\hline (only young children) & & & $(0.0973)$ & \\
\hline \multirow[t]{2}{*}{ Female Clothing/Male Clothing } & & & 0.1562 & ** \\
\hline & & & $(0.0369)$ & \\
\hline
\end{tabular}

Source: ENIGH, 1992 and 2000. Sample includes married households with children where the husband and the wife are between 18 and 54 years old. We divide each expenditure category by total expenditures to obtain shares. Column (1) and (2) report mean shares for 1992 and 2000 respectively. Column (3) reports coefficients on the 2000 dummy for the respective expenditure category. Additioanl controls in the regression include total expenditures, number of children aged less than 3, number of children aged 3-5 and total number of children. 